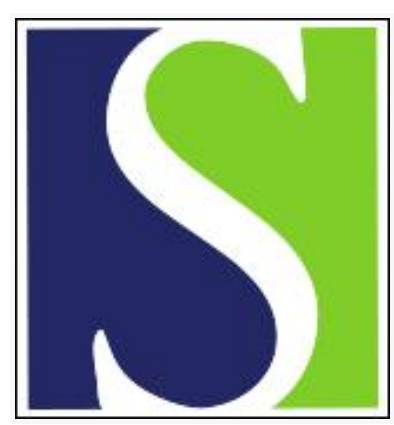

Scand J Work Environ Health 1996;22(2):112-118

https://doi.org/10.5271/sjweh.119

Issue date: Apr 1996

Partition coefficients between human blood or adipose tissue and air for aromatic solvents

by Pierce CH, Dills RL, Silvey GW, Kalman DA

Key terms: floor cleaners; handworker; neurophysiology

This article in PubMed: www.ncbi.nlm.nih.gov/pubmed/8738889

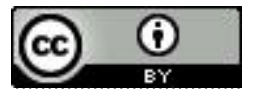




\title{
Partition coefficients between human blood or adipose tissue and air for aromatic solvents
}

\author{
by Crispin H Pierce, PhD, ${ }^{1}$ Russell L Dills, PhD, ${ }^{1}$ Guy W Silvey, MS, ${ }^{2}$ David A Kalman, PhD
}

\begin{abstract}
Pierce CH, Dills RL, Silvey GW, Kalman DA. Partition coefficients between human blood or adipose tissue and air for aromatic solvents. Scand J Work Environ Health 1996;22:112-8.

Objectives The partitioning of lipophilic toxicants into blood and into adipose tissue plays an important role in the physiological distribution and toxicology of these substances. The partition coefficients between blood and air and adipose tissue and air were determined for widely used aromatic solvents in an in vitro test system using human tissue samples.

Methods Samples of whole venous blood $(\mathrm{N}=35)$ were drawn from 10 subjects. In addition, samples of perirenal and epididymal adipose tissue were obtained from F344 rats, along with subcutaneous, omental, or inguinal adipose tissue from 43 patients who had undergone surgery. Portions of each tissue were injected into vials for equilibration with atmospheres containing deuterated and nondeuterated organic solvents. Gas chromatographic headspace analysis was then used to determine the partition coefficients between blood and air and adipose tissue and air.

Results The mean partition coefficients between human blood and air or adipose tissue and air were 334 (SE 11) (adipose tissue) for benzene; 1764 (SE 49) (adipose tissue) for ethylbenzene; 3184 (SE 84) (adipose tissue) for styrene; 18.3 (SE 0.24) (blood) and 962 (SE 32) (adipose tissue) for toluene; 35.2 (SE 0.45) (blood) and 2460 (SE 63) (adipose tissue) for o-xylene; 31.9 (SE 0.45) (blood) and 1919 (SE 53) (adipose tissue) for $m$-xylene; and 39.0 (SE 0.70) (blood) and 2019 (SE 102) for $p$-xylene. Regression analyses revealed coefficients of determination of 0.88 (human) and 0.98 (rat) between blood and air and log tissue and air. A value of 0.98 was found for partition coefficients between rat and human adipose tissue.

Conclusions The partition coefficients between blood and air and adipose tissue and air were strongly correlated. The partitioning of aromatic solvents into rat adipose tissue is predictive of partitioning into human adipose tissue.
\end{abstract}

Key terms benzene, distribution, ethylbenzene, fat, physiologically based pharmacokinetics, styrene, toluene, toxicokinetics, xylene.

The distribution of lipophilic toxicants into adipose tissue plays a pivotal role in the kinetics of these substances (1). During the onset of systemic exposure, toxicants accumulate in all tissues that have partition coefficients between tissue and blood that are greater than one. After exposure ceases, toxicants are slowly released from these tissues into blood. The accumulation of lipophilic toxicants in adipose tissue thus results in prolonged internal exposure after external exposure ceases. Adipose tissue, blood, and all blood-perfused tissue concentrations of a lipophilic toxicant are therefore affected by the partition coefficient between adipose tissue and blood $(2,3)$. The partition coefficient between tissue and blood is commonly determined by dividing the tissue-air coefficient by the blood-air coefficient (4).
The toxicologic importance of solvent partitioning has been demonstrated in measurements of solvents in subcutaneous adipose tissue after controlled exposure (5) and after occupational exposure (6); these measurements have been valuable in estimating the slow rates of solvent loss from this tissue. The long-term presence of lipophilic toxicants in the adipose tissue of nonoccupationally exposed persons has been demonstrated in the United States by the National Human Adipose Tissue Survey (7), in which the five toxicants most frequently detected in 14000 specimens analyzed over the period $1970-1992$ included benzene (96\%), styrene (100\%), toluene $(91 \%)$, and xylenes $(100 \%)$.

Partition coefficients are useful predictors of pharmacological and toxicologic effects. Partition coefficients

1 Department of Environmental Health, School of Public Health and Community Medicine, University of Washington, Seattle, Washington, United States.

2 Intel Corporation, Hillsboro, Oregon, United States.

Reprint requests to: Dr C Pierce, Department of Environmental Health, Box 357234, University of Washington, Seattle, WA 98195-7234, USA. 
between adipose tissue and air, oil and air, and blood and air have been found to correlate with the narcotic potency of numerous chemicals, including chloroform, ether, and chlorinated aliphatic hydrocarbons $(8,9)$. General anesthetic agents with higher partition coefficients between blood and air are associated with a more rapid onset of narcosis and slower elimination through exhalation, while higher partition coefficients between adipose tissue and air produce narcosis at lower tissue concentrations (10). Geyer et al (11) found that partitioning of the lipophilic toxicants tetrachlorodibenzo-p-dioxin (TCDD) and dieldrin into adipose tissue is inversely correlated with toxicity in animal species; they suggested (3) that this relationship exists for many toxicants and species.

The partition coefficients between blood and air and adipose tissue and air are integral components of physiological models (12) that simulate blood and tissue levels of toxicants in test species and humans (13-15). Sensitivity analyses of such models (16), including those done in our own laboratory, have identified partitioning coefficients between both blood and air and adipose tissue and air as important determinants of toxicokinetics. A simulation study by Sato et al (17) found that the partitioning of organic solvents into adipose tissue had pronounced effects on the profiles of the blood and urinary concentration curves.

Human toxicokinetic analyses $(4,18)$ have relied on the determination of the partition coefficient between tissue and air using animal tissues $(12,19)$. The aim of our work was to determine the values of the partition coefficient between blood and air for toluene and the xylenes in human blood and to perform a comprehensive study of the tissue-air coefficients for benzene, ethylbenzene, styrene, toluene, and $o^{-}, m^{-}$, and $p$-xylene in human adipose tissues. Perdeuterated solvents were included in this analysis to provide information supporting their use in our laboratory as tracers of solvent kinetics following controlled human exposures.

\section{Materials and methods}

\section{Atmosphere generation and vial equilibration}

For determinations of the blood-air coefficients, the solvent atmosphere was produced by a commercial dynamic vapor generator (model 450 dynacalibrator, VICI Metronics, Santa Clara, California, United States). Because of the greater partitioning of solvent vapor into fat compared with blood, the initial solvent vapor concentrations for the tissue-air determinations had to be greater so as to remain above the quantitation limit after equilibration. As such, static test atmospheres were prepared for the tissue-air determinations by adding liquid solvents to an empty aluminum scuba tank (11.7 1). The tank was then pressurized to 700 psi $(4.8 \mathrm{MPa})$ with nitrogen and then warmed to $50^{\circ} \mathrm{C}$ in a water bath. The temperature of the tank at the regulator was kept constant, and external surfaces were insulated. For determinations of both partition coefficients, the solvent-containing atmosphere from the dynacalibrator or tank was discharged at approximately $10 \mathrm{l} \cdot \mathrm{min}^{-1}$ through insulated tubing to a 5.1-1 glove box. For the blood-air determinations, each atmosphere contained three solvents at concentrations of approximately $100 \mathrm{ppm}$; the tissue-air determinations used concentrations of approximately 1000 ppm for each of two to four solvents (20) at room temperature and pressure. The glove box contained uncapped autosampler vials (target style, $2.0 \mathrm{ml}$ nominal volume; National Scientific Company, Lawrenceville, Georgia, United States) and was kept under positive pressure. After a 20 -min equilibration period, the vials were capped with tetrafluoroethylene/chlorobutyl rubber crimp-top seals while inside the glove box. Because of nitrogen enrichment the atmosphere was kept below the lower explosion limits both in the tank and in the glove box in the tissue-air experiments (21). A flash arrestor was placed in line between the scuba tank and the glove box.

\section{Tissue collection and preparation}

Venous blood samples ( $5 \mathrm{ml}, \mathrm{N}=35$ ) were collected from male volunteers $(\mathrm{N}=10)$ into Vacutainer ${ }^{(1)}$ vials treated with citrate or ethylene-diamine-tetraacetic acid, and then stored at $5^{\circ} \mathrm{C}$ and analyzed within $4 \mathrm{~h}$. Test vials for the blood-air determination were injected with $200 \mu \mathrm{l}$ of blood using a glass intradermal syringe $(0.5 \mathrm{ml}$ with 26 gauge needle, Becton, Dickinson \& Company, Rutherford, New Jersey, United States). Both the reference (atmosphere only) and test vials (atmosphere and blood) were placed in an orbital shaker $(220 \mathrm{rpm})$ for $10 \mathrm{~min}$ at $37^{\circ} \mathrm{C}$. The blood-air values were determined from five replicates (aliquots) of each sample.

Perirenal and epididymal adipose tissues from male F344 rats were collected and pooled together so that a comparison could be made with previous tissue-air determinations (12) and with results found using human tissues. Samples of subcutaneous, omental, or inguinal adipose tissue (normally discarded) were obtained from 43 patients undergoing various surgical procedures. Each $10-100 \mathrm{~g}$ sample was drained of any residual liquid and homogenized with a Polytron PCU-2 tissue homogenizer (Kinematica, Lucerne, Switzerland). Portions (approximately $30 \mathrm{mg}$ ) of each homogenate were then loaded into syringes and injected into the vials containing the solvent atmosphere. Tissue sample mass was determined by weighing each vial before and after tissue injection. The sample volume was calculated using a nominal adipose tissue density of $0.908 \mathrm{~g} \cdot \mathrm{ml}^{-1}(19)$. For human tissues, $3-12$ replicate portions of each tissue homogenate from 5-16 subjects, resulting in a total of 21 to 
84 vials, were used for each solvent. This study was approved by the University of Washington Human Subjects Division.

\section{Gas chromatographic analysis}

Initial experiments demonstrated that solvents equilibrated rapidly $(<20 \mathrm{~min}$ ) between the headspace and tissue at $37^{\circ} \mathrm{C}$. Vials were allowed to equilibrate for $30 \mathrm{~min}$ and were maintained at this temperature during the analyses. Injections of vial headspace $(125 \mu \mathrm{l})$ were performed by an autosampler, as previously described (20); solvent concentrations were measured using a Hewlett-Packard 5840 gas chromatograph with flame ionization detection. The gas chromatographic conditions were as follows: initial temperature $45^{\circ} \mathrm{C}$, initial time $1 \mathrm{~min}$, rate $10^{\circ} \mathrm{C} \cdot \mathrm{min}^{-1}$, final temperature $140^{\circ} \mathrm{C}$, hydrogen carrier gas at $1.35 \mathrm{ml} \cdot \mathrm{min}^{-1}$, and $30 \mathrm{~m} \mathrm{DB}-20$ wax column (inner diameter $0.25 \mathrm{~mm}$ ). The coefficient of variation for repeated analyses of the analytes from the reference vials was $10-12 \%$, and for those from the headspace of blood samples it was $12-15 \%$. The variation of the measurement of the analyte concentration in vials containing adipose tissue was higher and showed more variation between compounds: toluene $6 \%$, ethylbenzene and xylene $10-18 \%$, and benzene $23 \%$. The response was linear for all analytes over the measured range. No interfering peaks were found, as demonstrated by blank samples.

To check for solvent losses from the headspace during the course of the chromatographic analysis, five vials containing test atmosphere but no tissue homogenate were sampled at the beginning and end of each sequence;

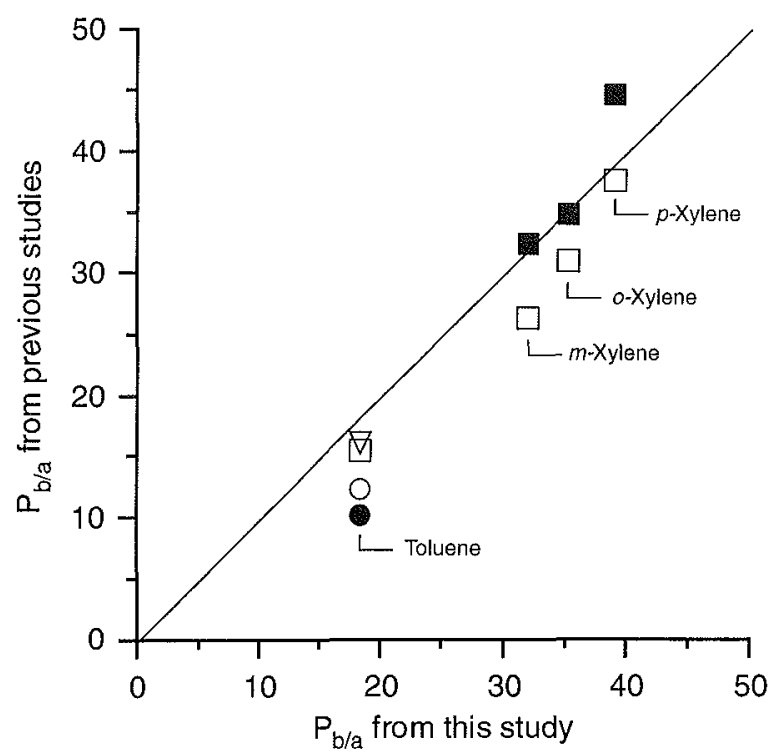

Figure 1. Comparison of the human blood-air partition coefficient $\left(\mathrm{P}_{\mathrm{b} / \mathrm{a}}\right)$ data from this study with those from previous studies. The line has a slope of $\uparrow$ and $r=0.96$. ( from reference 9, 0 from reference 23 ,

$\square$ from reference $12, \square$ from reference $8, \nabla$ from reference 20 ) during the experiments with a large number of vials $(\geq 75)$, five vials were analyzed in the middle of each sequence as well. To inspect further for analytic variability and partitioning equilibrium over the course of the analysis, 2-10 samples of homogeneous beef or rat adipose tissue were also sampled at the beginning and end of each sequence. No differences were detected in the blank or animal tissue standard vials over the course of the analyses. Moreover, no bias was found in an examination of the partition coefficient versus tissue mass.

\section{Data and statistical analyses}

Partition coefficients were determined using the mass balance-derived equation $\mathrm{P}_{\mathrm{b} / \mathrm{a}}$ or $\mathrm{P}_{\mathrm{t} / \mathrm{a}}=\left[\mathrm{C}_{\text {ref }}\left(\mathrm{V}_{\text {vial }}\right)-\right.$ $\left.\mathrm{C}_{t}\left(\mathrm{~V}_{\text {vial }}-\mathrm{V}_{\mathrm{t}}\right)\right] /\left[\mathrm{C}_{\mathrm{b}}\left(\mathrm{V}_{\mathrm{t}}\right)\right](12)$, where $\mathrm{P}_{\mathrm{b} / \mathrm{a}}$ is the partition coefficient between blood and air and $\mathrm{P}_{\mathrm{t} / \mathrm{a}}$ is that between adipose tissue and air, $\mathrm{C}_{\text {ref }}$ and $\mathrm{C}_{1}$ are the solvent concentrations in the reference and sample vial, respectively, and $V_{\text {vial }}$ and $V_{t}$ are the volumes of the empty vial (2.07 \pm $0.02 \mathrm{ml}$ ) and tissue sample, respectively.

Because deuterated and nondeuterated solvent isomers were simultaneously equilibrated with the same tissue samples, paired t-tests were used to determine the isomeric differences in the blood-air and tissue-air values. The differences between the individual tissue donors were assessed by an analysis of variance. The measured tissue-air values were compared with previously measured values, the blood-air values, and various measures of chemical polarity, including the dipole moment, the log octanol-water partition coefficient, and the dielectric constant, across solvents. Linear regression analysis was performed to determine possible correlations between these parameters and the tissue-air and log tissueair values for both the human and rat tissues, and between the tissue-air values determined for human and rat tissues.

\section{Results}

The measured mean blood-air partition coefficients were 18.3 (SE 0.24) for ${ }^{~} \mathrm{H}_{8}$-toluene, 18.1 (SE 0.24) for ${ }^{2} \mathrm{H}_{8}$-toluene, 35.2 (SE 0.45) for ${ }^{1} \mathrm{H}_{10}$-o-xylene, 35.1 (SE 0.42) for ${ }^{2} \mathrm{H}_{10^{-0}}$-xylene, 31.9 (SE 0.45) for ${ }^{1} \mathrm{H}_{10}-\mathrm{m}$ xylene, 31.6 (SE 0.52) for ${ }^{2} \mathrm{H}_{10}-m$-xylene, 39.0 (SE 0.70) for ${ }^{1} \mathrm{H}_{10}-p$-xylene, and 38.4 (SE 0.72) for ${ }^{2} \mathrm{H}_{10}-p$-xylene. A comparison of these values with those determined previously for human blood is presented in figure 1 . Using paired t-tests, we found differences between the perdeuterated versus nondeuterated blood-air values only for $p$-xylene $(\mathrm{P}=0.003)$. No interindividual differences in the blood-air values were detected with the analysis of variance.

The tissue-air data for benzene, ${ }^{1} \mathrm{H}_{8}$ - and ${ }^{2} \mathrm{H}_{8}$-styrene, toluene, and $o$ - and $m$-xylene are presented for the ex- 
Table 1. Animal-derived partition coefficients between adipose tissue and air.

\begin{tabular}{|c|c|c|c|c|c|c|c|c|c|}
\hline \multirow[t]{3}{*}{ Solvent } & \multicolumn{9}{|c|}{ Adipose tissue source } \\
\hline & \multicolumn{3}{|c|}{ F344 Rats (this study) } & \multicolumn{3}{|c|}{ F344 Rats (reference 12) } & \multicolumn{3}{|c|}{ Rabbits (reference 19) } \\
\hline & $N$ & Mean & $\begin{array}{c}\text { Standard } \\
\text { error }\end{array}$ & $N$ & Mean & $\begin{array}{r}\text { Standard } \\
\text { error }\end{array}$ & $\mathrm{N}$ & Mean & $\begin{array}{c}\text { Standard } \\
\text { error }\end{array}$ \\
\hline Benzene & 45 & 366 & 33 & $3-15$ & 499 & 12 & 5 & 626 & $5^{a}$ \\
\hline${ }^{1} \mathrm{H}_{8}$-Styrene & 20 & 3270 & $153^{b}$ & $3-15$ & 3476 & 73 & .. & .. &. \\
\hline${ }^{2} \mathrm{H}_{8}$-Styrene & 20 & 3169 & 164 & .. & .. & .. & .. &.. &.. \\
\hline Toluene & 45 & 959 & 69 & $3-15$ & 1021 & 11 & 5 & 1923 & $12^{a}$ \\
\hline o-Xylene & 45 & 2930 & 260 & $3-15$ & 1877 & 132 & .. & .. & .. \\
\hline$m$-Xylene & 40 & 2325 & 194 & $3-15$ & 1859 & 93 & .. & .. & .. \\
\hline
\end{tabular}

a Calculated from $P_{\text {blood-air }}$. $P_{\text {sissub-blood }}$ data in reference 19.

b ${ }^{1} \mathrm{H}_{8}$ - and ${ }^{2} \mathrm{H}_{8}$-styrene were significantly different in the paired t-test $(P<0.005)$.

periment with F344 rat tissue in table 1 with comparisons with values determined for F344 rat tissue (12) and rabbit tissue (19) in earlier studies. Figure 2 presents a graphic comparison of rat tissue-air values with those previously measured for rats (12), rabbits (19), and lard (22).

In the comparison of the partition coefficients between adipose tissue and air in four tissue groups (human, this study; F344 rats, this study; F344 rats, reference 12; and lard, reference 22) with the blood-air partition coefficients and measures of chemical polarity, the following coefficients of determination were obtained: 0.95 (SD 0.05) for the blood-air coefficient and the $\log$ tissue-air coefficient, 0.73 (SD 0.06) for the $\log$ octanol-water partition coefficient and log tissue-air coefficient, 0.58 (SD 0.13) for the dielectric constant and the tissue-air partition coefficient, and 0.35 (SD 0.25) for the dipole moment and the $\log$ tissue-air partition coefficient.

Table 2 presents the human tissue-air coefficients for benzene and the perdeuterated and nondeuterated iso-

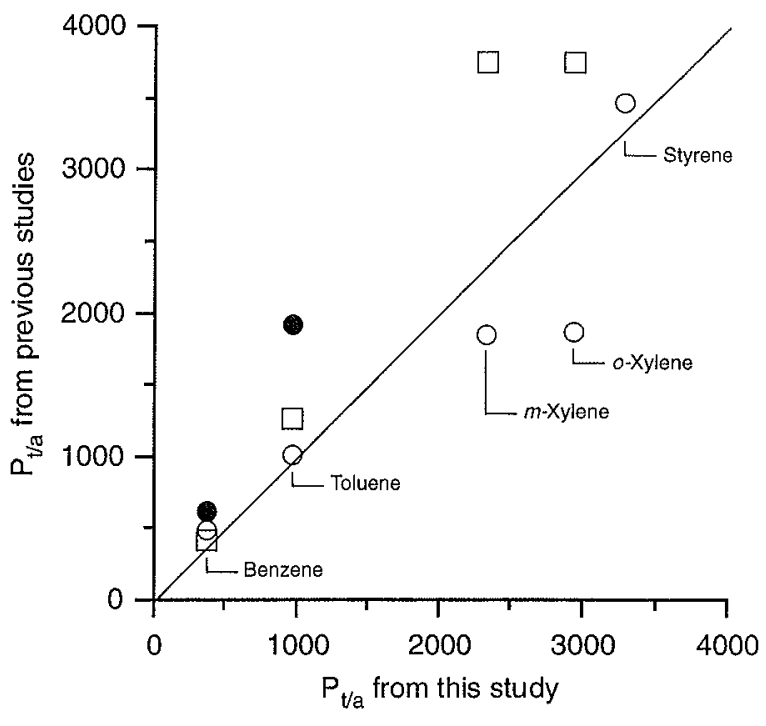

Figure 2. Comparison of the partition coefficient $\left(P_{t / 2}\right)$ data for adipose tissues from F344 rat tissues in this study with those from previous studies using animal tissues. The line has a slope of 1 and $r=0.85$. ( from reference 19, 0 from reference 12, $\square$ from reference 22)

Table 2. Human adipose tissue-air partition coefficient data.

\begin{tabular}{|c|c|c|c|c|c|}
\hline \multirow[t]{2}{*}{ Chemical } & \multirow{2}{*}{$\begin{array}{l}\text { Number of } \\
\text { individuals }\end{array}$} & \multirow{2}{*}{$\begin{array}{c}\text { Total } \\
\text { determinations }\end{array}$} & \multicolumn{3}{|c|}{ All determinations } \\
\hline & & & Mean & $\begin{array}{l}\text { Standard } \\
\text { error }\end{array}$ & $\begin{array}{c}\text { Coefficient of } \\
\text { variation } \\
(\%)\end{array}$ \\
\hline Benzene $^{\mathrm{a}}$ & 8 & 69 & 334 & 11 & 27 \\
\hline $1 \mathrm{H}_{10}$-Ethylbenzene ${ }^{\mathrm{a}}$ & 71 & 71 & 1764 & 49 & 24 \\
\hline${ }^{2} \mathrm{H}_{10}$-Ethylbenzene ${ }^{a}$ & 7 & 71 & 1630 & 59 & 31 \\
\hline${ }^{1} \mathrm{H}_{8}-$ Styrene ${ }^{\mathrm{a}, \mathrm{b}}$ & 7 & 40 & 3184 & 84 & 17 \\
\hline${ }^{2} \mathrm{H}_{8}{ }_{8}-$ Styrene ${ }^{\mathrm{a}}$ & 7 & 40 & 3111 & 82 & 17 \\
\hline $\mathrm{H}_{8}$-Toluene & 16 & 84 & 962 & 32 & 31 \\
\hline $2 \mathrm{H}_{8}$-Toluene & 12 & 34 & 1017 & 29 & 16 \\
\hline${ }^{1} \mathrm{H}_{10^{-}}-\mathrm{O}-\mathrm{Xylene} \mathrm{e}^{\mathrm{a}}$ & 8 & 73 & 2460 & 63 & 22 \\
\hline${ }^{2} \mathrm{H}_{10}-0$-Xylene ${ }^{\mathrm{a}}$ & 5 & 52 & 2402 & 82 & 25 \\
\hline${ }^{1} H_{10}-m$-Xylene $e^{a, b}$ & 5 & 50 & 1919 & 53 & 20 \\
\hline${ }^{2} H_{10}-m$-Xylene ${ }^{a}$ & 5 & 50 & 1785 & 60 & 24 \\
\hline${ }^{1} H_{10}-p-X y l e n e^{a_{1} b}$ & 7 & 21 & 2019 & 102 & 23 \\
\hline${ }^{2} \mathrm{H}_{10}-p-$-Xylene ${ }^{\mathrm{a}}$ & 7 & 21 & 1828 & 88 & 22 \\
\hline
\end{tabular}

a Differences between individuals were significant in an analysis of variance $(P<0.05)$.

b Deuterated and nondeuterated isomers were different in the paired $t$-test $(P<0.05)$. 


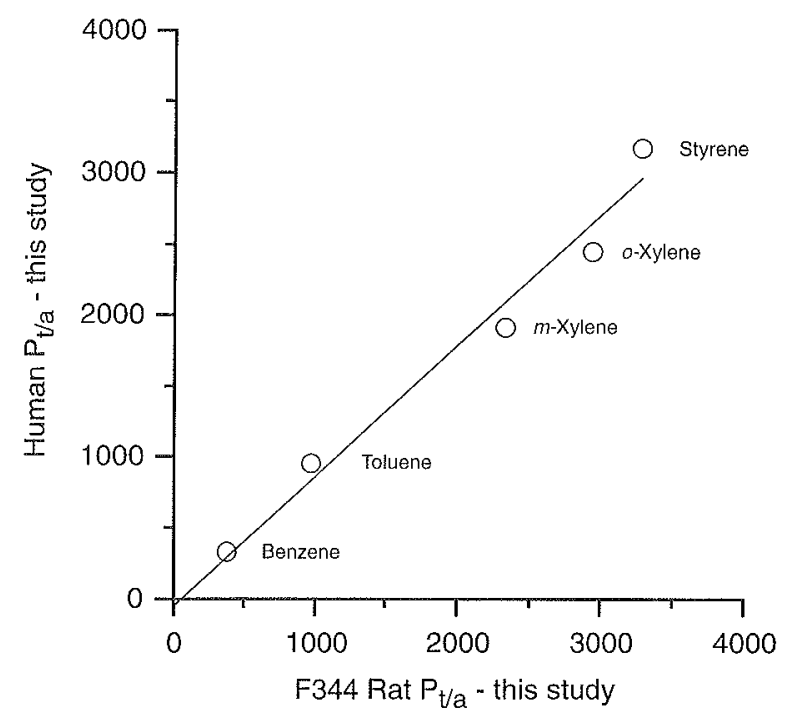

Figure 3. Correlation of the partition coefficient between adipose tissue and air $\left(\mathrm{P}_{\mathrm{t} / \mathrm{a}}\right)$ as measured for human (Phuman) and rat (Prat) tissues. The line indicates the least squares fit to the data $\left(r^{2}=0.98\right)$ and is defined by Prat $=1.09$. Phuman +41 .

mers of ethylbenzene, styrene, toluene, $o$-xylene, $m$-xylene, and $p$-xylene. Figure 3 presents a graphic comparison of the tissue-air values determined for human and rat tissues.

Two tissue samples obtained during liposuction procedures on the same individual, six months apart, were also used for partition coefficient determination. The mean partition coefficients for the ${ }^{1} \mathrm{H}_{10^{-}}$and ${ }^{2} \mathrm{H}_{10}$-ethylbenzene and ${ }^{1} \mathrm{H}_{10^{-}}$and ${ }^{2} \mathrm{H}_{10^{-}} \mathrm{O}$-xylene determined in these samples $(\mathrm{N}=11)$ [1338 (SE 46), 1451 (SE 57), 1959 (SE 103) 2044 (SE 92), respectively] were lower $(\mathrm{P}<0.05$, t-test) than those determined from other samples (table 2). The liposuction surgery yielded a mixture of adipose tissue with some blood; the higher proportion of blood contained in the liposuction-derived tissue is likely to have produced the lower tissue-air values.

Small but statistically significant lower tissue-air values were found in paired $t$-tests of perdeuterated versus nondeuterated solvents, in the case of styrene (rat $3 \%$ and human $2 \%$ lower), and $m$ - and $p$-xylene (human $8 \%$ and $9 \%$ lower, respectively) (tables 1 and 2). Significant interindividual differences of approximately $15 \%$ were found for the tissue-air partition coefficient between the human tissue samples and all the solvents except ${ }^{1} \mathrm{H}_{8}-$ and ${ }^{2} \mathrm{H}_{8}$-toluene (table 2).

\section{Discussion}

This is the first publication, to our knowledge, of a comprehensive determination of partition coefficients between adipose tissue and air using human tissues. Fisero-
va-Bergerova et al (9) determined tissue-air values of 425 (SE 50) and 962 (SE 188) for benzene and toluene, respectively, using three replicates of human tissue taken from five cadavers at autopsy. Sato et al (19) performed five replicates using tissue from a single human subject and found values of 406 (SD 10) and 1296 (SD 92) for the same solvents. Our values of 334 (SE 11) and 962 (SE 32) (table 2) are within 26 (range $0-26$, mean 16)\% of these previously reported values.

Previous studies have determined tissue-air partition coefficients with the use of rat tissues (12), rabbit tissues (19), and lard (22). Figure 2 illustrates a general agreement of the values found from F344 rat tissues in our study with those previously determined in animal tissues. Our measurements of rat tissue-air coefficients closely correlated $\left(\mathrm{r}^{2}=0.83\right)$ with values determined by Gargas et al (12), both studies using F344 rat perirenal and epididymal adipose tissues. Despite the larger sample sizes, the standard error values were larger in our study than those found in the Gargas et al study. This result may in part be explained by differential tissue preparation - Gargas et al used a homogenized mixture of $0.5 \mathrm{ml}$ of tissue and $1.5 \mathrm{ml}$ of saline, whereas we used only homogenized tissue. The use of smaller tissue volumes without the addition of a threefold volume of saline may more closely reflect the true heterogeneity of adipose tissue and variability in the tissue-air values.

The blood-air partition coefficients were very closely associated with the $\log$ tissue-air values $\left[\mathrm{r}^{2}=0.95\right.$ (SE 0.05)]. An analysis of the values found by Gargas et al (12) showed a similar correlation $\left(r^{2}=0.94\right.$ for bloodair versus tissue-air, and $r^{2}=0.80$ for blood-air versus $\log$ tissue-air). This relationship was also reflected in the similarity of the slopes $(0.024-0.036)$ and intercepts $(2.4-2.5)$ of the regression lines. Among the measures of chemical polarity, the log octanol-water partition coefficients were the most closely associated with the log tissue-air coefficient $\left[\mathrm{r}^{2}=0.73\right.$ (SE 0.06)]. In contrast, Fiserova-Bergerova et al (9) examined 11 volatile $\mathrm{C}_{2}-$ $\mathrm{C}_{8}$ hydrocarbons and halogenated hydrocarbons, and found "no reasonable relationship" between the log octanol-water and the adipose tissue-air coefficients without the addition of a dummy constant in the regression equation. Across the parameters tested, the blood-air coefficient was the best predictor of rat and human tissue-air values.

Deuterated blood-air and tissue-air values were lower than nondeuterated values for the most lipophilic substances (styrene, $m$-xylene, and $p$-xylene). Deuterium substitution in these solvents may thus result in slightly increased volatility, decreased lipophilicity, or both.

Given the finding of interindividual differences for adipose tissue but not for blood, and the range of coefficients of variation of $16-31 \%$ for the tissue-air coefficient versus $7.2-11.1 \%$ for blood-air coefficients, adi- 
pose tissue was found to be a more heterogeneous tissue between subjects. This finding is consistent with the knowledge that, as a fluid, blood is more homogeneous than adipose tissue, which is composed of several cell types (eg, adipocytes, endothelial cells) of varying proportions and of fatty acids with varying degrees of saturation. Interindividual differences in human tissue-air partition coefficients could thus be due to differences in the tissues between individuals, between sites of tissue removal, or both. However, the average tissue-air coefficient of variation for human values was $23 \%$, compared with the value of $16 \%$ using F344 rat tissues, suggesting that although intersubject and sampling site differences do contribute, most variability is due to analytic procedures. This conclusion is also supported by the finding of a nonsignificant correlation $\left(r^{2}=0.051\right)$ between the number of individuals sampled and the resulting coefficient of variation (table 2). If interindividual variability had contributed greatly to the average tissue-air value, a closer relationship between these variables would have been expected.

Higher solvent blood-air partition coefficients are associated with a more rapid onset of central nervous system effects, a longer time to reach steady-state blood levels during constant exposure, and a more gradual loss through exhaled air after the cessation of exposure. Based upon results of this study, these effects would be expected in the following order, given exposure at the same concentration: $p$-xylene $>o$-xylene $\cong$ m-xylene $>$ toluene. Higher partition coefficients between adipose tissue and air are associated with deeper anesthesia among anesthetic agents, a longer time to reach adipose tissue steady-state levels during constant exposure, and a more gradual loss from adipose tissue (and therefore from the entire body) after the cessation of exposure. Results found in this study indicate that these effects would be expected in the following order: styrene $>0$-xylene $>p$ xylene $\cong m$-xylene $>$ ethylbenzene $>$ toluene $>$ benzene.

The determination of partition coefficient information using human blood and adipose tissues is essential to the understanding of solvent toxicokinetics. The close association between the tissue-air values of humans and F344 rats (slope of 1.09 and $r^{2}=0.98$ ) (figure 3), however, indicates similar solvent partitioning characteristics. These observations together provide refinement in the development of models to better predict human risk from organic solvent exposure, while offering assurance that previously used approaches have been useful.

\section{Acknowledgments}

We would like to thank the following persons for collecting the human adipose tissue samples: Judy Westby,
Vicky Hughes, and surgeons E Patchen Dellinger, Martin Schreiber, W Scott Helton, Mica Sinanan, D Eugene Strandness, Alexander E Clowes, Roger E Moe, David R Byrd, Richard Rand, Carlos A Pellegrini, David Needle, and James D Perkins.

Financial support was provided by the Superfund Basic Research program, NIEHS ES 04696. Funding for $\mathrm{G}$ Silvey was provided by a Department of Energy Industrial Hygiene graduate fellowship.

\section{References}

1. Engström J, Bjurström R, Åstrand I, Övrum P. Uptake, distribution and elimination of styrene in man: concentration in subcutaneous adipose tissue. Scand J Work Environ Health 1978:4:315-23.

2. Pierce CH, Tozer TN. Styrene in adipose tissue of nonoccupationally exposed persons. Environ Res 1992;58:230-5.

3. Geyer H, Scheunert I, Rapp K, Gebefugi I, Steinberg C, Kettrup A. The relevance of fat content in toxicity of lipophilic chemicals to terrestrial animals with special reference to dieldrin and 2,3,7,8-tetrachlorodibenzo-p-dioxin (TCDD). Ecotoxicol Environ Saf 1993;26(1):45-60.

4. Tardif R, Laparé S, Krishnan K, Brodeur J. Physiologically based modeling of the toxicokinetic interaction between toluene and m-xylene in the rat. Toxicol Appl Pharmacol 1993; 120:266-73.

5. Carlsson A, Ljungquist E. Exposure to toluene: concentration in subcutaneous adipose tissue. Scand $J$ Work Environ Health $1982 ; 8: 56-62$.

6. Nise G, Attewell R, Skerfving S, Ørbæk P. Elimination of toluene from venous blood and adipose tissue after occupational exposure. Br J Ind Med 1989;46:407—11.

7. United States Environmental Protection Agency. Archive of human monitoring specimens: disposition to private sector or other governmental party; notice of availability. Fed Regist 1993;58(220):60625-8.

8. Sato A, Nakajima T. Partition coefficients of some aromatic hydrocarbons and ketones in water, blood and oil. $\mathrm{Br} \mathrm{J}$ Ind Med 1979;36:231—4.

9. Fiserova-Bergerova V, Tichy M, Carlo FJD. Effects of biosolubility on pulmonary uptake and disposition of gases and vapors of lipophilic chemicals. Drug Metab Rev 1984; 15(5\&6): 1033-70.

10. Gilman A, Goodman L, Rall T, Murad F, editors. Goodman and Gilman's the pharmacological basis of therapeutics. 7th edition. New York (NY): Macmillan Publishing Co, 1985.

11. Geyer H, Scheuntert I, Rapp K, Kettrup A, Korte F, Griem H, et al. Correlation between acute toxicity of 2,3,7,8-tetrachlorodibenzo-p-dioxin and total body fat content in mammals. Toxicology 1990;65(1-2):97-107.

12. Gargas ML, Burgess RJ, Voisard DE, Cason GH, Andersen ME. Partition coefficients of low-molecular-weight volatile chemicals in various liquids and tissues. Toxicol Appl Pharmacol 1989;98:87-99

13. Ramsey JC, Andersen ME. A physiologically based description of the inhalation pharmacokinetics of styrene in rats and humans. Toxicol Appl Pharmacol 1984;73:159-75.

14. Fiserova-Bergerova V, editor. Modeling of inhalation exposure to vapors; uptake, distribution, and elimination; vol II. 
Boca Raton (FL): CRC Press, 1983.

15. Fiserova-Bergerova V, Teisinger J. Pulmonary styrene vapor retention. Ind Med Surg 1965;34(8):620—2.

16. Hetrick D, Jarabek A, Travis C. Sensitivity analysis for physiologically based pharmacokinetic models. J Pharmacokinet Biopharm 1991;19(1):1-20.

17. Sato A, Endoh K, Kaneko T, Johanson G. A simulation study of physiological factors affecting pharmacokinetic behaviour of organic solvent vapours. Br J Ind Med 1991;48:342-7.

18. Clewell H III, Andersen M. Dose, species, and route extrapolation using physiologically based pharmacokinetic models. In: Subcommittee on Pharmacokinetics in Risk Assessment. Pharmacokinetics in risk assessment: workshop proceedings,. Washington (DC): National Academy Press, 1987:159—82.

19. Sato A, Nakajima T, Fujiwara Y, Hirosawa K. Pharmacokinetics of benzene and toluene. Int Arch Arbeitsmed 1974;33:
169-82.

20. Dills R, Ackerlund W, Kalman D, Morgan M. Blood/air partition coeficient determinations: automation and improvement of the equilibrium partitioning in closed systems method. J Ex Anal Environ Epidemiol 1994;4:229-45.

21. Coward $H$, Jones $G$. Limits of flammability of gasses and vapors. Washington (DC): Bureau of Mines, 1952.

22. Sherwood R. Ostwald solubility coefficients of some industrially important substances. Br J Ind Med 1976;33:106-7.

23. Lindqvist $T$. Partition coefficients of blood/air and water/air for some commonly used solvents. Amsterdam: Excerpta Medica 1978:16-167. International congress series, industrial and environmental xenobiotics, no 440.

Received for publication: 27 February 1995 